\title{
CRIMEAN CONGO HEMORRHAGIC FEVER IN PAKISTAN: CASE CONTROL STUDY, 2012-2015
}

\author{
Ansari J A A $^{1}$ Mumtaz A Khan ${ }^{1}$, Ranjha M A ${ }^{1}$, Rathore T R ${ }^{1}$, Khan $\mathbf{G}^{2}$, Salman $\mathbf{M}^{3}$, Nazia Hassan ${ }^{1}$, Akram \\ Qammar ${ }^{1}$, Aamer Ikram ${ }^{4}$
}

${ }^{1}$ Field Epidemiology \& Disease Surveillance Division, National Institute of Health, Islamabad, Pakistan.

${ }^{2}$ Department of Cytogenetics, Public Health Laboratories Division, National Institute of Health, Islamabad, Pakistan.

${ }^{3}$ Department of Virology, Public Health Laboratories Division, National Institute of Health, Islamabad, Pakistan.

${ }^{4}$ Executive Director, National Institute of Health, Islamabad, Pakistan.

Correspondence: Jamil A. Ansari, E-mail: jam62aa @gmail.com, Contact: +92519255575

\begin{abstract}
Background: Sporadic cases of CCHF continue to occur since first known fatality in 1976 in Pakistan. This study was conducted to identify the population groups more at risk to acquire CCHF infection.

Methods: A case-control study comprising record review of the lab investigations sent to National Institute of Health, Islamabad was conducted from 2012 to 2015 . A case was defined as any blood sample confirmed to be CCHF using RT-PCR testing. A total of 255 confirmed cases and 510 sex matched controls were randomly selected during January 2012-December 2015. Controls were selected from the samples which tested negative for CCHF on RTPCR. Data from all suspected cases were collected on a structured questionnaire. Univariate and multivariate analysis was conducted to find associations using Epi-Info and SPSS.

Results: among 255 confirmed CCHF cases male were $80 \%$. Baluchistan reported maximum number of cases $(55 \%)$. The most affected age group was above 41 years $(n=143$, attack rate $0.45 / 100,000)$. In multivariate analysis the risk factors remained significantly associated with the CCHF were contact with Positive CCHF case (OR 3.77; $95 \% \mathrm{Cl}$ 2.49-5.71), health care workers (OR 3.76; 95\% Cl 2.22-6.36), butchers (OR 2.97; 95\% Cl 1.19-4.3.25), animal handlers (OR 2.55; 95\% Cl 1.12-2.72) and tannery workers (OR 2.13; 95\% Cl 1.22-2.72). Drivers and persons with travel history to endemic areas were significant in univaraite analysis but remained insignificant in multivariate analysis.

Conclusion: Contact with the positive CCHF case and workers like health care professionals, butchers, animal handlers and tannery workers are at increased risk for CCHF. Educational intervention is recommended to control the CCHF.

Keywords: Animal handler, butchers, cchf, risk factors
\end{abstract}

\section{Introduction}

Crimean Congo Hemorrhagic Fever (CCHF), a zoonotic disease with high mortality rate in humans is caused by CCHF virus (CCHFV) from family Bunyaviridae (1).CCHFV is transmitted to vertebrates by bites of Hyloma ticks and cases have also reported with history of direct contact with blood or tissues of infected animals and human (2).CCHF is a disease with high case fatality rate in the neighboring countries including Afghanistan (CFR 33\%) (3), Iran (CFR 17.6\%) (4), Turkey (CFR; $20 \%$ ) (5) and India CFR; $30-50 \%$. (6)

Initially CCHF appeared in Crimea during 1944 (7) and to date geographically CCHF is present in most of the areas of Asia, Africa, Middle East and Europe (8). During 1976, the first CCHF case was reported from Rawalpindi, Pakistan (9). After this, sporadic cases continued to occur from different parts of the country in different years but from the last decade every year a considerable number of samples are being received at the National Institute of Health (NIH), Islamabad. CCHF is endemic in Pakistan and is emerging as a serious public health issue with a case fatality rate ranging from $20 \%$ to $40 \%$.

Epidemiologic information plays a very vital role in controlling the morbidity and mortality of communicable diseases. Based on epidemiological evidence a public health manager can easily recommend in-time interventions, guide public health policy, develop guidelines, and ensure efficient resource allocation. There are several studies published previously on the same objective but with small sample size and in limited areas of the country with recommendation to increase sample size of better results. The current was planned with larger sample size and at National level for more 
reliable results. The aim of this study was to determine the epidemiologic features including age, sex, location, epidemiological risk factors associated with the transmission of the disease and seasonal variation experienced during 2012-2015 in Pakistan.

\section{Methodology}

A case-control study based on 255 laboratory confirmed cases and 510 sex matched controls was conducted during January 2012 through December 2015 at National Institute of Health, Pakistan. National Institute of Health is a National reference laboratory and CCHF samples from all over the Pakistan received at NIH with detailed case investigation forms.

WHO case definitions for suspected, probable and confirmed CCHF cases were followed according to which a patient with sudden onset of illness with high grade fever over $38.50 \mathrm{C}$ for more than 3 days and less than 10 days, especially in CCHF endemic area and in contact with sheep or other livestock (Shepherds, butchers and animal handlers) and fever does not respond to antibiotic or anti-malarial treatment was considered as suspected case of $\mathrm{CCHF}(10)$.

Suspected case with acute history of febrile illness 10 days or less and any of the two conditions; thrombocytopenia less than $50,000 / \mathrm{mm} 3$, petechial or purpuric rash, epistaxis, haematemesis, haemoptysis, blood in stools, ecchymosis, gum bleeding, other haemorrhagic symptoms and no known predisposing host factors for haemorrhagic manifestations was considered as probable case of CCHF (10).

Probable case with detection of viral nucleic acid by PCR in blood samples remained as confirmed cases of CCHF (10).

A sample size of 255 positive cases of CCHF was selected using Raosoft online sample size calculator with $95 \%$ confidence level. All the study subjects were selected with simple random sampling method. A total of 510 genders matched Controls with absence of clinical history of CCHF were randomly selected from the same communities from where the cases arose with proportion to the confirmed cases. Two controls were selected for each case. Province wise total population was taken to find out the attack rate of the disease.

Data from the cases and controls was collected on a standard case reporting Performa. The Performa includes variables like age, sex, occupation, history of tick bite, history of contact with livestock and history of slaughtering of livestock (Raw meat). Univeriate and multivariate analysis was performed using Epi info and SPSS.

\section{Results}

Among the cases $80 \%$ were male and $20 \%$ were female among controls $79 \%$ were male and $21 \%$ were female. Among the cases and controls the age group 16 years to 40 years remained maximum (cases $63 \%$, control $67 \%$ ). More than half $(55 \%)$ cases were reported from Balochistan province. The most common occupations among the case were butchers (18\%), animal handlers
(17\%), housewives and health care workers (14\%). (Table 1)

Table 1: Descriptive Characteristics of CCHF cases and controls, 2012-2015

\begin{tabular}{|c|c|c|}
\hline Characteristics & Cases $(\mathrm{n} \%)^{*}$ & Controls $(\mathrm{n} \%)^{*}$ \\
\hline $\begin{array}{c}\text { Gender } \\
\text { - Male } \\
\text { - Female }\end{array}$ & $\begin{array}{c}205(80 \%) \\
50(20 \%)\end{array}$ & $\begin{array}{l}403(79 \%) \\
107(21 \%)\end{array}$ \\
\hline $\begin{aligned} \text { Age } & \\
- & \leqslant 15 \text { Years } \\
& 16-40 \text { Years } \\
\bullet & \geqslant 41 \text { Years }\end{aligned}$ & $\begin{array}{c}11(4 \%) \\
161(63 \%) \\
83(33 \%)\end{array}$ & $\begin{array}{c}44(9 \%) \\
343(67 \%) \\
123(24 \%)\end{array}$ \\
\hline $\begin{array}{l}\text { Area/Province } \\
\text { - Islamabad } \\
\text { - Balochistan } \\
\text { - } \text { AJK } \\
\text { - FATA } \\
\text { - } \text { KPK } \\
\text { - Sunjab } \\
\text { - Sindh } \\
\end{array}$ & $\begin{array}{c}11(4 \%) \\
136(55 \%) \\
2(1 \%) \\
3(1 \%) \\
34(13 \%) \\
41(16 \%) \\
28(10 \%)\end{array}$ & $\begin{array}{c}43(8 \%) \\
233(46 \%) \\
5(1 \%) \\
3(1 \%) \\
102(20 \%) \\
86(17 \%) \\
38(7 \%) \\
\end{array}$ \\
\hline $\begin{array}{l}\text { Occupations } \\
\text { - HCW } \\
\text { - Animal Handlers } \\
\text { - } \text { Bannery Workers } \\
\text { - Drivers } \\
\text { - Housewives } \\
\text { - Labor } \\
\text { - Nothy }\end{array}$ & $\begin{array}{c}35(14 \%) \\
43(17 \%) \\
20(8 \%) \\
46(18 \%) \\
8(3 \%) \\
39(15 \%) \\
4(2 \%) \\
31(11 \%) \\
33(12 \%)\end{array}$ & $\begin{array}{c}40(8 \%) \\
24(5 \%) \\
14(3 \%) \\
36(7 \%) \\
4(1 \%) \\
34(6 \%) \\
94(18 \%) \\
158(31 \%) \\
106(21 \%)\end{array}$ \\
\hline
\end{tabular}

${ }^{*} n=$ number of cases and controls

The maximum affected age group was ?41 years and calculated attack rate was $0.45 / 100000$ persons in this age group while the second most affected age group was $16-40$ years with attack rate of $0.15 / 100,000$. The least affected age group was ?15 Years. (Table2)

Table 2: Attack Rate of CCHF per 100000 Person in Pakistan, 2012-2015 ( $n=255)$

\begin{tabular}{|l|l|l|l|}
\hline $\begin{array}{c}\text { Age } \\
\text { Groups }\end{array}$ & $\begin{array}{c}|c| \\
\text { Estimated } \\
\text { Population(Index } \\
\text { Mundi 2014) }\end{array}$ & $\begin{array}{c}\text { No. of } \\
\text { CCHF } \\
\text { Cases }\end{array}$ & $\begin{array}{c}\text { Attack } \\
\text { Rate/100000 }\end{array}$ \\
\hline$\cdots$ & $65,393,715$ & 11 & 0.01 \\
\hline $\begin{array}{l}16-40 \\
\text { Years }\end{array}$ & $112,289,315$ & 161 & 0.15 \\
\hline$\cdots-$ & $18,491,350$ & 83 & 0.45 \\
\hline Total & $196,174,380$ & 255 & \\
\hline
\end{tabular}

The CCHF disease remained the most affected in old age groups and economically active population. See visual comparison of age and gender of CCHF cases in Pakistan.(Figure 1)

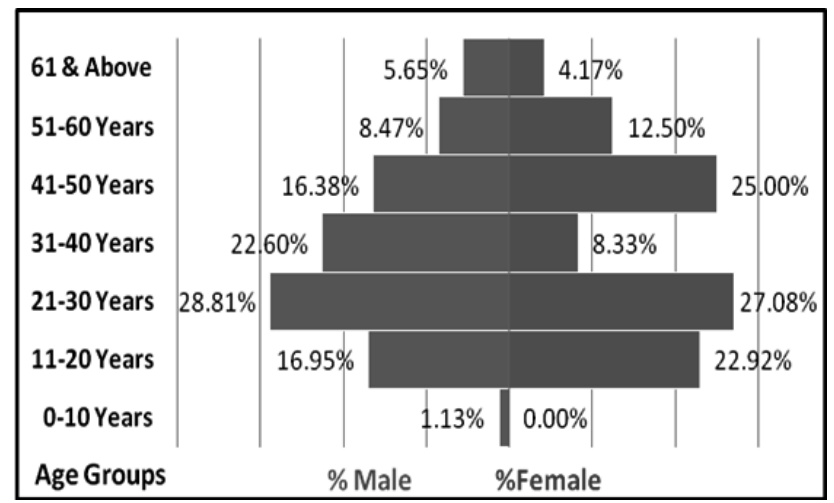

Figure 1: Age \& Gender Distribution among the CCHF cases, Pakistan, 2012-2105 ( $n=255)$ 
Maximum cases of CCHF $85 \%$ were reported from April to October each year which is related to more exposure with animals during spring season and migration of the animals across different areas of the country. (Figure 2)

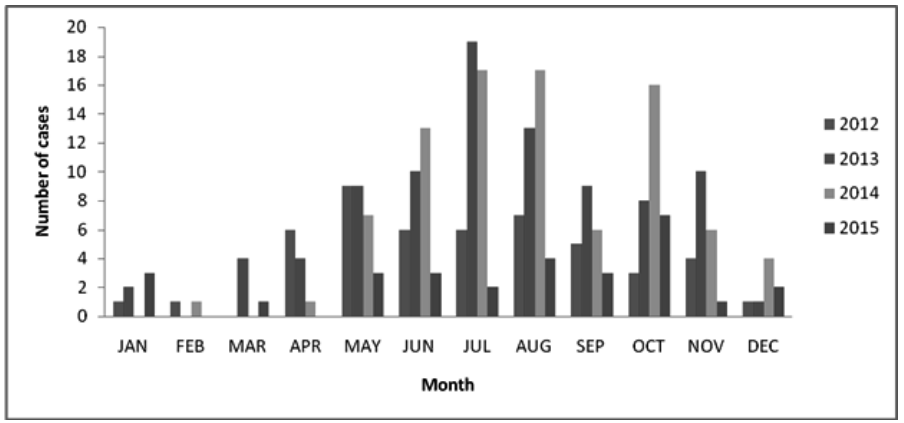

Figure 2: Month and Year wise reported cases in Pakistan, 2012-2015 ( $n=255)$

Among the total 255 cases, $69 \%$ had hemorrhagic manifestation, $59 \%$ had body aches, $86.7 \%$ had high grade fever and $26 \%$ showed petecheal rashes. (Figure 3)

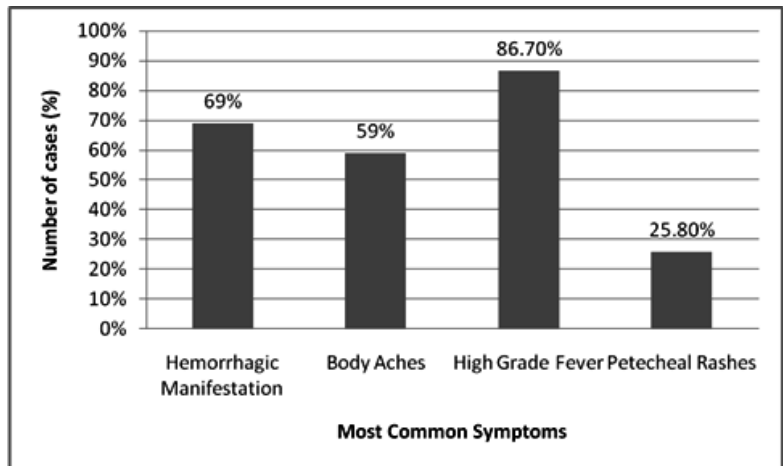

Figure 3: Most common symptoms among the CCHF cases in Pakistan, 2012-2015

In Univariate analysis The risk factors remained significantly associated with the CCHF were Driver (OR 4.08: 95\% Cl 1.22-15.7), Travel History (OR 3.32; 95\% Cl 1.93-5.77), Animal Handlers (OR 4.09; 95\% Cl 2.437.01), Tannery Workers (OR 3.01; 95\% Cl 1.496.19), Butchers (OR 2.89; 95\% Cl 1.81-4.63), Contact of Positive CCHF case (OR 2.08; 95\% Cl 1.43-3.03) and Health Care Workers (OR 1.86; 95\% Cl 1.14-3.02). Table

Table 3: Significant Risk factors associated with CCHF in Pakistan, 2012-2015

\begin{tabular}{|c|c|c|c|c|c|}
\hline Characteristics & Cases $(n \%)$ & $\begin{array}{l}\text { Controls } \\
(\mathrm{n} \%)\end{array}$ & $\begin{array}{l}\text { MLE Odd Ratio } \\
(95 \% \mathrm{Cl})^{\star \star \star}\end{array}$ & $\begin{array}{l}\mathrm{MH}^{\star *} \\
\text { Chi- } \\
\text { square }\end{array}$ & $\begin{array}{l}\text { P- } \\
\text { Value }\end{array}$ \\
\hline $\begin{array}{c}\text { Contact with } \\
\text { Confirmed case } \\
\qquad \text { Yes } \\
\text { No } \\
\end{array}$ & $\begin{array}{l}66(47.4 \%) \\
189(30.1 \%) \\
\end{array}$ & $\begin{array}{l}73(52.6 \%) \\
437(69.8 \%) \\
\end{array}$ & $2.08(1.43-3.03)$ & 15.2 & 0.00 \\
\hline $\begin{array}{l}\text { HCW (Doctors, } \\
\text { Paramedical) } \\
\text { - Yes } \\
\text { - No } \\
\end{array}$ & $\begin{array}{l}35(46.6 \%) \\
220(31.8 \%)\end{array}$ & $\begin{array}{l}40(53.4 \%) \\
470(68.2 \%) \\
\end{array}$ & $1.86(1.14-3.02)$ & 6.64 & $0.00^{*}$ \\
\hline $\begin{array}{l}\text { Animal Handlers } \\
\text { (Shepherd ?\& } \\
\text { Farmer) } \\
\text { : Yes } \\
\text { - No } \\
\end{array}$ & $\begin{array}{l}43(64.1 \%) \\
212(30.3 \%)\end{array}$ & $\begin{array}{l}24(35.9 \%) \\
486(69.7 \%)\end{array}$ & $4.09(2.43-7.01)$ & 31.3 & $0.00^{*}$ \\
\hline $\begin{array}{c}\text { Tannery Workers } \\
\text { - Yes } \\
\text { - No }\end{array}$ & $\begin{array}{l}20(58.8 \%) \\
235(32.1 \%)\end{array}$ & $\begin{array}{l}14(41.2 \%) \\
496(67.9 \%)\end{array}$ & $3.01(1.49-6.19)$ & 10.3 & $0.00^{*}$ \\
\hline
\end{tabular}

\begin{tabular}{|c|c|c|c|c|c|}
\hline 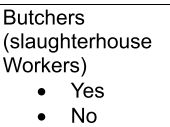 & $\begin{array}{l}46(56.1 \%) \\
209(30.6 \%)\end{array}$ & $\begin{array}{l}36(43.9 \%) \\
474(69.4 \%)\end{array}$ & $2.89(1.81-4.63)$ & 21.3 & $0.00^{*}$ \\
\hline $\begin{array}{l}\text { Drivers (Involved i } \\
\text { transportation of } \\
\text { Animal \& Animal } \\
\text { Skins) } \\
\text { - Yes } \\
\text { - No }\end{array}$ & $\begin{array}{l}8(66.6 \%) \\
247(32.8 \%)\end{array}$ & $\begin{array}{l}4(33.4 \%) \\
506(67.2 \%)\end{array}$ & $4.08(1.22-15.7)$ & 6.08 & 0.01 \\
\hline $\begin{array}{c}\text { Travelled History } \\
\text { (Endemic Areas) } \\
\text { - Yes } \\
\text { - No }\end{array}$ & $\begin{array}{l}36(60 \%) \\
219(31 \%)\end{array}$ & $\begin{array}{l}24(40 \%) \\
486(69 \%)\end{array}$ & $3.32(1.93-5.77)$ & 20.08 & $0.00^{*}$ \\
\hline
\end{tabular}

*significant at 0.001 confidence interval, ** Mental Henzel Chi-square test

*** maximum likelihood estimation odds ratio

In multivariate analysis drivers involved in the transportation of animals and person having travelling history of endemic areas remained in significant (Table 4).

Table 4: Multivariate analysis; Significant Risk factors associated with CCHF in Pakistan, 20122015

\begin{tabular}{|c|c|c|c|c|c|c|c|c|}
\hline \multirow[t]{2}{*}{ Characteristics } & \multirow[b]{2}{*}{$\mathrm{B}$} & \multirow[b]{2}{*}{ S.E. } & \multirow[b]{2}{*}{ Wald } & \multirow[b]{2}{*}{$\mathrm{df}$} & \multirow[b]{2}{*}{ Sig. } & \multirow[b]{2}{*}{$\operatorname{Exp}(B)$} & \multicolumn{2}{|c|}{$\begin{array}{c}95.0 \% \text { C.l.for } \\
\operatorname{EXP}(\mathrm{B})\end{array}$} \\
\hline & & & & & & & Lower & Upper \\
\hline Contact history & -.975 & .211 & 21.281 & 1 & .000 & 3.77 & 2.49 & 5.71 \\
\hline $\mathrm{HCW}$ & -.978 & .268 & 13.297 & 1 & .000 & 3.76 & 2.22 & 6.36 \\
\hline Animal Handlers & -1.864 & .287 & 42.338 & 1 & .000 & 2.55 & 1.12 & 2.72 \\
\hline Tannery Workers & -1.793 & .391 & 21.022 & 1 & .000 & 2.13 & 1.22 & 3.58 \\
\hline Butchers & -1.627 & .256 & 40.318 & 1 & .000 & 2.97 & 1.19 & 3.25 \\
\hline Drivers & -2.073 & .635 & 10.672 & 1 & .001 & 1.26 & .236 & $1 . .36$ \\
\hline Travelled History & -1.069 & .314 & 11.597 & 1 & .001 & 1.33 & .186 & 1.635 \\
\hline Constant & 8.779 & 1.012 & 75.303 & 1 & .000 & $6.494 \mathrm{E} 3$ & & \\
\hline
\end{tabular}

\section{Discussion}

This study has highlighted the risk factors significantly associated with the transmission of CCHF. Close contact with confirmed case in the community, health care facility and at home, health care workers i.e. doctors, nurses, laboratory technicians, animal handlers; farmers, shepherd, tannery workers, butchers; working at slaughter houses, remained the significant risk factors during 2012-2015. Animal handlers including farmers and shepherd have direct contact with animals especially goat, sheep, cattle and chances of the tick bites become maximum. Butchers having direct contact with the raw meat and blood if they come in contact with the infected animal's blood, tissue or raw meat, they may acquire the infection. Similarly the skin of the infected animals can spread the infection among the tannery workers. A study regarding the risk factors associated with the CCHF was published in Iran and has provided that the most important risk factors for CCHF case were conditions of close contact with livestock (such animal husbandry and slaughtering livestock. (11).

Health care workers including doctors, nurses, and laboratory technicians are at risk with close contact with the patient. A nosocomial outbreak of CCHF with 6 patients has reported in Iran during 2009 including one 
index case and 5 were contact cases out of which 4 were healthcare workers. Infection spreaded by percutaneous exposure to case, and probably by direct contact with blood, clothes and sheets (12). Health care workers and close family members are highly recommended to take precautionary measures to control the transmission of CCHF. A short report on nosocomial outbreak of CCHF in Rawalpindi, Pakistan during 2002 showed that identified index case expired shortly after admission to the hospital. Two of the healthcare workers became secondary cases; one of them expired on day 13 after coming in contact with the index case. The other secondary case was successfully treated with oral ribavirin (13).

In Pakistan the most affected age group was 41 and above years while the second most affected age group was 16-40 years and male were more frequent during the period 2012-2015. Afghanistan has showed the median age around 27 and male were more prevalent $(57 \%)(3)$. It is concluded that the working age group (16-40 years) in Pakistan is at high risk and more exposed to the risk factors responsible for the transmission of disease. A study conducted in Iran has also provided that the maximum of the CCHF cases reported among the 20-40 years of age groups. (14). It was found that the sign and symptoms presented as fever $(86.7 \%)$, Hemorrhagic manifestation (69\%), body aches (59\%) and petechiae (25.8\%). Center for Disease Control and Prevention has also reported same sign \& symptoms during CCHF i.e. high fever, petechiae (red body spots), stomach pain, vomiting and uncontrolled bleeding at injection sites (15).

The current study has identified the seasonal variation of $\mathrm{CCHF}$ in Pakistan and it was reported that $85 \%$ cases were reported during April to October. Animal movement from one area to other area remains high in Pakistan and possibility of animal-human contact remains high. This animal movement is due the weather conditions in different areas. Almost similar results have been reported by a study conducted in Turkey, around $81 \%$ cases reported during May through July (16). Similar seasonal trend is present in the other neighboring countries of Pakistan.

Geographically, the sporadic cases reported from all over Pakistan; however Balochistan remained the most affected province and has reported $57.3 \%$ of the total cases during the period 2012-2015. The maximum number of cases has been reported from Quetta, Balochistan. Livestock rising is the major occupation for over $70 \%$ rural population of the Balochistan province (17). A large number of animals move constantly throughout the year for grazing and have massive migration of animals to all over the country (18). Baluchistan is adjacent to Iran having common business, where exchange of different food items and agriculture occurs frequently (19). This trade can play a role in the spread of CCHF between both countries. Sindh in neighboring to Baluchistan has reported $11.1 \%$ of cases during 2012-2015. This may be linked with animal, meat and skin trade between the two provinces. Study limitations

Recall biases are possible to exist. Two controls were selected for each case ideally there should be three controls for each case and selection biases may be possible. Controls were selected from the same community we can also select control from the other communities/localities. Confounders were checked using multivariate analysis, stratification will be beneficial for more better results. Data was taken from the records it should be better to direct interview the cases.

\section{Conclusion}

Close contact, Animal handling, butchering, transportation and professions like farmers, butchers, shepherds, health care workers and tannery workers are at risk of CCHF. Early diagnosis and timely management of CCHF cases can be improved by periodic health education of community at high risk including men and women working in agriculture sector, slaughter houses, animal husbandry and those working in health care setups. At healthcare facilities patients with probable CCHF should be isolated under strict barriers; nursing and health workers should use personal protective equipments (PPEs). All contaminated material should be handled and de-contaminated or disposed off safely. Family members of a CCHF confirmed case should be provided with PPEs for caring the patient. In case of death, safe burial practices must be exercised. Acaricides (Acaricides are pesticides that kill members of the arachnid subclass Acari, which includes ticks and mites) should be used on domestic animals to control ticks 10-14 days prior to slaughter or export. Capacity building/ refresher training of health care staff especially in endemic areas is also recommended.

\section{Reference}

1. Burt FJ, Swanepoel R, Shieh WJ, Smith JF, Leman PA, Greer PW, Coffield LM, Rollin PE, Ksiazek TG, Peters CJ, Zaki SR,1997. Immunohistochemical and in situ localization of Crimean-Congo hemorrhagic fever (CCHF) virus in human tissues and implications for CCHF pathogenesis. Arch Pathol Lab Med 1219: 839-846.

2. Vorou R, Pierroutsakos IN, Maltezou HC: Crimean-Congo hemorrhagic fever. CurrOpin Infect Dis 2007, 20:495-500.

3. Mofleh J, Ahmad Z et al.,Crimean-Congo haemorrhagic fever outbreak investigation in the Western Region of Afghanistan in 2008. East Mediterr Health J. 2012 May;18(5):522-6.

4. Keshtkar-Jahromi M, Sajadi MM, Ansari H, Mardani M, Holakouie-Naieni K. CrimeanCongo hemorrhagic fever in Iran, antiviral.2013.07.007. Epub 2013 Oct;100(1):20-8.

5. Karti SS, Odabasi Z, Korten V et al., "Crimean- 
Congo hemorrhagic fever in Turkey". Emerg Infect Dis. 2004 Aug;10(8):1379-84

6. Ramesh Verma, Pardeep Khanna, Shankar Prinja, Meena Rajput, Crimean-Congo haemorrhagic fever: An outbreak in India, Australas Med J, Published online 2011 Nov 30. doi: 10.4066/AMJ.2011.701 PMCID: PMC3562913

7. Leshchinskaya EV, 1965. Crimean hemorrhagic fever (in Russian). Trudy Inst Polio Virus EntsefAkad Med Nauk SSSR 7: 226-236.

8. Shope RE. Introduction to hemorrhagic fever viruses. In: Goldman L, Ausiello D, editors. Cecil Textbook of Medicine. 22nd ed. Philadelphia: Saunders; 2004. p. 2020-25.

9. Burney MI, Ghafoor A, Saleen M, Webb PA, Casals J, 1980. Nosocomial outbreak of viral hemorrhagic fever caused by Crimean Hemorrhagic fever-Congo virus in Pakistan, January 1976. Am J Trop Med Hyg 29: 941-947.

10. Ajoint program of National Institute of Health and World Health Organization, Survillance Case Definations booklet. December 2012

11. Shahrokhlzadi, KouroshHolakouieNaieni, Seyed Reza Madjdzadeh, AbolhassanNadim,. "Crimean-Congo hemorrhagic fever in Sistan and Baluchestan Province of Iran, a case-control study on epidemiological characteristics" International Journal of Infectious Diseases (2004) 8, 299-306

12. Naderi HR, Sarvghad MR, Bojdy A et al., Nosocomial Outbreak of Crimean-Congo Haemorrhagic Fever, Epidemiol Infect. 2011 Jun;139(6):862-6. Epub 2010 Aug 27.

13. Muhammad NaumanAthar, Haider Zaigham Baqai, Masood Ahmad, Mohammad Ali Khalid Naghman Bashir, Ahsan Maqbool Ahmad, Abbas Hayat Balouch, Kaukab Bashir,. " Short report: Crimean-Congo Hemorrhagic Fever Outbreak in Rawalpindi, Pakistan", The American Journal of Tropical Medicine and Hygiene, Sep 2003

14. Seyed Mehdi Tabatabaei, Abdulghaffar Hassan zehi, Abdul razzaghPakzad, Mehdi Mohammdi, AbdoulhossainMadani., "Factors Influencing Crimean-Congo Hemorrhagic Fever Risk Perceptions in the General Population, Southeast Iran".Int J Infect. 2014 June; 1(1): e18150

15. Crimean-Congo Hemorrhagic Fever Fact sheet, 24 April 2012, www.cdc.com

16. Sisman A. "Epidemiologic Features and Risk Factors of Crimean-Congo Hemorrhagic Fever in Samsun Province, Turkey". J Epidemiol. 2012 Dec 1

17. Www.Balochistan.gov.pk/Livestock and dairy development

18. Zahid Ali Khan., "Balochistan Factor in Pak-Iran
Relations: Opportunities and Constraints" A Research Journal of South Asian Studies Vol. 27, No. 1, January-June 2012, pp. 121-140

19. M. Afzal, A.N. Naqvi., Livestock Resources of Pakistan: Present Status and Future trends Quarterly SCIENCE VISION Vol.9 No.1-2 (Jul Dec, 2003) \& 3-4 (Jan - Jun, 2004) 